\title{
Alteration in Neonatal Nutrition Causes Perturbations in Hypothalamic Neural Circuits Controlling Reproductive Function
}

\author{
Emilie Caron, ${ }^{1}$ Philippe Ciofi, ${ }^{3,4}$ Vincent Prevot, ${ }^{1}$ and Sebastien G. Bouret ${ }^{1,2}$ \\ ${ }^{1}$ INSERM, Jean-Pierre Aubert Research Center, U837, University Lille 2, Lille 59045, France, ${ }^{2}$ The Saban Research Institute, Neuroscience Program, \\ Children's Hospital Los Angeles, University of Southern California, Los Angeles, California 90027, ${ }^{3}$ INSERM U862, Neurocentre Magendie, 33077 Bordeaux, \\ France, and ${ }^{4}$ Université de Bordeaux, 33077 Bordeaux, France
}

It is increasingly accepted that alterations of the early life environment may have lasting impacts on physiological functions. In particular, epidemiological and animal studies have indicated that changes in growth and nutrition during childhood and adolescence can impair reproductive function. However, the precise biological mechanisms that underlie these programming effects of neonatal nutrition on reproduction are still poorly understood. Here, we used a mouse model of divergent litter size to investigate the effects of early postnatal overnutrition and undernutrition on the maturation of hypothalamic circuits involved in reproductive function. Neonatally undernourished females display attenuated postnatal growth associated with delayed puberty and defective development of axonal projections from the arcuate nucleus to the preoptic region. These alterations persist into adulthood and specifically affect the organization of neural projections containing kisspeptin, a key neuropeptide involved in pubertal activation and fertility. Neonatal overfeeding also perturbs the development of neural projections from the arcuate nucleus to the preoptic region, but it does not result in alterations in kisspeptin projections. These studies indicate that alterations in the early nutritional environment cause lasting and deleterious effects on the organization of neural circuits involved in the control of reproduction, and that these changes are associated with lifelong functional perturbations.

\section{Introduction}

A large body of epidemiological and animal studies indicates that adverse early environments, including changes of the intrauterine and early postnatal nutritional environments, may alter physiological processes and cause pathological conditions. For example, both neonatal overfeeding and underfeeding predispose individuals to develop obesity and diabetes (MartinGronert and Ozanne, 2005; Levin, 2006; Plagemann, 2006; Godfrey et al., 2010; Sullivan and Grove, 2010). Research in humans and a variety of animal models also support a link between early life nutrition and optimal reproductive function (Wade et al., 1996; Hileman et al., 2000; Ahima, 2004; FernandezFernandez et al., 2006). Undernutrition caused by anorexia or

Received Dec. 7, 2011; revised June 29, 2012; accepted July 3, 2012.

Author contributions:V.P. and S.G.B. designed research; E.C., V.P., and S.G.B. performed research;P.C. and S.G.B. contributed unpublished reagents/analytic tools; E.C., V.P., and S.G.B. analyzed data; V.P. and S.G.B. wrote the paper.

This work was supported by the National Institutes of Health (Grant DK84142, to S.G.B.), the "Fondation pour la Recherche Médicale" and Danone Institute (to S.G.B.), the EU FP7 Integrated project (Grant agreement no. 266408, "Full4Health," to S.G.B.), and the "Agence Nationale de la Recherche" (Grant ANR-08-JCJC-0055-01, to S.G.B.; Grant ANR-09-BLAN-0267 to V.P.; and Grant ANR 11 BSV1 02102 to S.G.B. and P.C.). E.C. was a Ph.D. student supported by a fellowship from the French "Ministère délégué à la Recherche et aux Nouvelles Technologies." We thank Dr. A. Caraty for providing valuable reagents.

Correspondence should be addressed to Dr. Sebastien G. Bouret, The Saban Research Institute, Neuroscience Program, Children's Hospital Los Angeles, University of Southern California, 4650 Sunset Boulevard, MS\#135, Los Angeles, CA 90027. E-mail: sbouret@chla.usc.edu.

DOI:10.1523/JNEUROSCI.6074-11.2012

Copyright $\odot 2012$ the authors $\quad 0270-6474 / 12 / 3211486-09 \$ 15.00 / 0$ calorie restriction delays the onset of puberty in humans (Kennedy and Mitra, 1963; Foster and Olster, 1985), disrupts estrous cycles, and delays the postpartum return to estrus in sexually mature animals (Wade et al., 1996). Childhood obesity and neonatal overfeeding have also generated considerable concern in recent decades (Ebbeling et al., 2002). Remarkably, obese individuals share a phenotype similar to that of calorie-restricted individuals, i.e., a variety of alterations in the reproductive axis, including decreased fertility (Bray, 1997; Brewer and Balen, 2010). However, in contrast to undernutrition, which causes delayed puberty, childhood obesity induces precocious puberty in girls (Wyshak and Frisch, 1982; Herman-Giddens et al., 1997; Biro et al., 2006; Ong et al., 2006; Kaplowitz, 2006; Euling et al., 2008; Burt Solorzano and McCartney, 2010; Walvoord, 2010).

The onset of puberty and the regulation of fertility are primarily governed by a complex neural network in the hypothalamus. The key components of this network include neurons that produce gonadotropin-releasing hormone $(\mathrm{GnRH})$ and kisspeptin (Hill et al., 2008; Clarkson et al., 2010; Lehman et al., 2010). Proper activation of each of these neuronal systems is required for the onset of puberty and normal regulation of the hypothalamic-pituitary-gonadal (HPG) axis (Mason et al., 1986; de Roux et al., 2003; Seminara et al., 2003; Gottsch et al., 2004; Clarkson et al., 2008; Herbison et al., 2008; Mayer and Boehm, 2011). GnRH neurons are located in the preoptic region of the hypothalamus in rodents, and they send extensive projections to the median eminence, releasing their neurohormone into the 
portal vasculature and stimulating the secretion of gonadotropin hormones to initiate puberty and support fertility (Herbison, 2006; Ojeda and Skinner, 2006). Kisspeptin neurons also comprise an important hypothalamic neural system involved in the neural control of gonadotropin secretion. Kisspeptin is expressed by two distinct populations of neurons located in the anteroventral periventricular nucleus (AVPV) and the arcuate nucleus of the hypothalamus (ARH) (Gottsch et al., 2004; Clarkson and Herbison, 2006; d'Anglemont de Tassigny et al., 2007; Lehman et al., 2010; Cravo et al., 2011; Mayer and Boehm, 2011). Each of these neuronal populations projects to hypothalamic regions triggering puberty and ovulation, such as the median preoptic nucleus (MEPO), as well as directly to GnRH neurons (Clarkson and Herbison, 2006; Yeo and Herbison, 2011). Importantly, the hypothalamus also contains neurons that have the ability to sense and alter their activity in response to fluctuations in food and nutrient availability (Elmquist et al., 2005; Hill et al., 2008).

Although early life nutrition appears to be an important determinant for optimal mammalian reproduction, the precise neurobiological mechanisms that contribute to this effect are poorly understood. In the present study, we used a well established divergent litter size mouse model of postnatal overnutrition and undernutrition to determine whether changes in growth and nutrition during this critical developmental period influence puberty and later fertility through changes in the organization of hypothalamic circuits involved in reproduction.

\section{Materials and Methods}

Animals. Offspring of FVB mice (Charles River), produced in our mouse colony, were used in these studies. To manipulate preweaning nutrition, litter size was manipulated beginning on P4 by randomly distributing pups among mothers such that large litters (LL; underfed) had 15 pups ( 7 males and 8 females or 8 males and 7 females), normal litters had 8 pups (NL; 4 males and 4 females), and small litters (overfed) had 3 pups (SL; 2 males and 1 female or 1 male and 2 females). Animals used for adult studies were housed four per cage and given access to chow and water $a d$ libitum after weaning (P21). Animal usage was in compliance with and approved by the Institutional Animal Care and Use Committee of the Saban Research Institute of Children's Hospital of Los Angeles and by the INSERM guidelines for the Care and Use of laboratory animals. The animals and experiments used in this study were also in accordance with the European Communities Council Directive of November 24th, 1986 (86/609/EEC) regarding mammalian research. In all experiments, each group consisted of offspring from at least four litters.

Reproductive phenotyping. Body weight was measured with an analytical balance every $2 \mathrm{~d}$ from P4 to P21 (weaning) and weekly from P21 through P60. Starting on P21, mice were inspected daily for imperforation of the vaginal membrane ("vaginal opening," VO). Thereafter, vaginal smears were examined daily to detect the first ovulation (used as a marker of puberty onset), as described previously (Nelson et al., 1990; Prevot et al., 2005). Uterine weight was also measured in P24 and P27 female mice. Adult breeding capacities were evaluated by mating adult females with a control stud male and recording the number of litters per month (fertility index).

Ovariectomy and hormone assay. Briefly, P24 mice were deeply anesthetized with an intraperitoneal injection of ketamine and xylazine and the ovaries were aseptically removed. Mice were killed $96 \mathrm{~h}$ later and serum luteinizing hormone (LH) levels were measured by ELISA (Rodent LH kit, Endocrine Technologies). The rationale for ovariectomizing mice at P24 was to assess the function of the hypothalamic-pituitary unit near the time of puberty.

Neuroanatomical studies. At P16, animals from each group were perfused through the heart with a $4 \%$ paraformaldehyde solution and the brains were processed for DiI axonal labeling of ARH and AVPV neurons as described previously (Bouret et al., 2004a, 2008; Polston and Simerly, 2006). Briefly, an insect pin was used to place a small crystal of DiI
(1, $1^{\prime}$-dioctadecyl-3,3,3', $3^{\prime}$-tetramethylindocarbocyanine perchlorate; Invitrogen) $(10-25 \mu \mathrm{m}$ in diameter) into the ARH or AVPV of each brain, under visual guidance. After 1 week (for AVPV implants) or 4 weeks (for ARH implants) of incubation at $37^{\circ} \mathrm{C}$, sections were collected from each brain through the hypothalamus and evaluated with both conventional fluorescence and confocal microscopy. It was determined through pilot studies that a 1 week incubation period was sufficient for maximal labeling of AVPV $\rightarrow$ MEPO projections, and that a 4 week incubation period was sufficient for maximal labeling of $\mathrm{ARH} \rightarrow \mathrm{MEPO}$ projections.

Immunohistochemistry was also used to determine whether manipulating postnatal nutrition resulted in long-term effects on the pattern of kisspeptin projections. Briefly, anesthetized P32, P37, and P60 (adult) diestrous female mice were perfused transcardially with $4 \%$ paraformaldehyde, the brains were frozen and sectioned at a thickness of $30 \mu \mathrm{m}$, and the samples were processed for immunofluorescence as described previously (Bouret et al., 2004b). Briefly, sections were incubated with a rabbit anti-kisspeptin (1:5000; Dr. A. Caraty, INRA-Tours, Nouzilly, France) and a guinea-pig anti-neurokinin B (NKB, 1:3000; Dr. Philippe Ciofi, INSERM, Bordeaux, France) (Ciofi et al., 2006), and the primary antibodies were localized with a biotinylated goat anti-rabbit IgG (1:500, Vector Laboratories) and an Alexa Fluor 568 goat anti-guinea pig (1:200, Invitrogen). Tyramide signal amplification was accomplished by placing the sections in an avidin-biotin solution (Vectastain) for $1 \mathrm{~h}$, followed by incubation in tyramide signal amplification solution for $20 \mathrm{~min}$ according to the manufacturer's instruction (TSA-Indirect kit, New England Nuclear Life Science). Deposited biotin was detected with Alexa 488conjugated streptavidin (1:500, Invitrogen). Another series of sections was incubated with a rabbit anti-GnRH (1:3000; Dr. Gérard Tramu, University of Bordeaux, Bordeaux, France) and the primary antibodies were localized with an Alexa Fluor 568 goat anti-rabbit (1:200, Invitrogen). Sections were counterstained with bis-benzamide (1:10,000, Invitrogen) to visualize cell nuclei and coverslipped with buffered glycerol ( $\mathrm{pH} 8.5)$.

Quantitative analysis of fiber density. For quantification, 4-6 animals per experiment were analyzed. A series of 20 adjacent optical sections was collected at $1 \mu \mathrm{m}$ intervals through the MEPO (2 sections/animal) and paraventricular nucleus (PVH; 2 sections/animal) of animals from each group, by using a Zeiss LSM 710 confocal system equipped with a $20 \times$ objective. The nomenclature used in this study corresponds to that described in the rat brain atlas of Swanson (Swanson, 1992). Only MEPO sections throughout Figures 28-29 of the Franklin and Paxinos (2008) mouse brain atlas were analyzed. Image analysis was performed using the ImageJ image analysis software (NIH) (Bouret et al., 2004a,b, 2008). Briefly, each image plane was binarized to isolate labeled fibers from the background and to compensate for differences in fluorescence intensity. The integrated intensity was then calculated for each image, which reflects the total number of pixels in the binarized image and is proportional to the total length of labeled fibers in the image. This procedure was performed on each image plane in the stack, and the values for all image planes in a stack were summed. Three categories of labeled fibers were quantified: (1) relative density of kisspeptin-immunoreactive (IR) fibers; (2) relative density of NKB-IR fibers; (3) relative density of doubly labeled kisspeptin + NKB fibers.

Statistical analysis. Statistical analysis was performed using GraphPad PRISM (version 5.0a). Statistical significance was determined using an unpaired Student's $t$ test. Body weights were compared between groups by two-way ANOVA followed by the Student Newman-Keuls multiple range test, with postnatal diet and age as factors. A $p$ value $<0.05$ was considered statistically significant.

\section{Results}

\section{Importance of postnatal nutrition for growth and} reproductive functions

To manipulate nutrition specifically during postnatal (preweaning) life, we used a divergent litter size mouse model of perinatal overnutrition and undernutrition. In our mouse model, litter size was manipulated beginning on postnatal day 4 (P4) by randomly 
distributing pups among mothers such that LL (underfed) had 15 pups, NL (normal fed) had 8 pups, and SL (overfed) had 3 pups. Litter size manipulation was associated with changes in growth as revealed by a significant decrease and increase in the preweaning body weight curves of underfed and overfed animals, respectively, compared with normal fed mice (Fig. 1). As early as P10, overfed females displayed heavier body weights compared with control animals, and these changes in body weight persisted into adulthood (Fig. 1) (ANOVA, main factor "postnatal diet," $F=159.2, \mathrm{df}=9, p<0.05)$. In contrast, neonatally underfed females exhibited a lighter body weight as early as P8 and this change in body weight persisted at weaning and into adulthood (Fig. 1) (ANOVA, main factor "postnatal diet," $F=$ 63.1, $\mathrm{df}=3, p<0.05)$.

The onset of puberty, which is typically defined as the time of $\mathrm{VO}$ and first estrus, was delayed in neonatally undernourished mice (Fig. 2A-C). Whereas VO occurred at $28.5 \pm 0.3 \mathrm{~d}$ in normal nourished mice, it was observed at $31.8 \pm 0.4 \mathrm{~d}$ in neonatally underfed mice (Fig. $2 A)(t=3.023, \mathrm{df}=$ $6, p<0.05)$. Similarly, the mean age of first vaginal estrus was $32.4 \pm 0.4 \mathrm{~d}$ in normal fed mice compared with $38.5 \pm 0.6 \mathrm{~d}$ in neonatally underfed mice (Fig. $2 B)(t=$ 3.945 , df $=6, p<0.05)$. In contrast, no significant differences in either the day of VO or the day of first estrus were observed between normally fed animals and neonatally overfed mice (Fig. 2A,B).

Uterine weight is a reliable physiological index of estrogen secretion (Ojeda and Skinner, 2006). To determine whether ovarian estrogen output was influenced by neonatal nutrition, we measured uterine weight in peripubertal (P24) females raised in small, normal, and large litters. Undernourished P24 females displayed a smaller uterine weight compared with SL and NL control mice (Fig. 2D) $(t=3.723$, df $=6, p<0.05$ ).

Not only did changes in neonatal nutrition affect the onset of puberty, they also had long-term effects on later reproductive capability and fertility. Animals raised in large litters displayed a reduced fertility index, as evaluated by the number of litters per month (Fig. $2 E)(t=4.237, \mathrm{df}=6, p<0.05)$. Notably, fertility index was also reduced in adult females raised in small litters (Fig. $2 E)(t=2.673$, df $=7, p<0.05)$, indicating that both postnatal undernutrition and overnutrition reduced adult reproductive performance.

\section{Neonatal nutrition perturbs the $\mathrm{LH}$ response to ovariectomy} In normal animals, ovariectomy relieves the hypothalamicpituitary unit of steroid-dependent inhibitory feedback control, causing an increase in circulating levels of pituitary gonadotropins, including LH (Grumbach and Styne, 1998; Ojeda and Skinner, 2006). To evaluate the function of the hypothalamicpituitary-gonadal axis, we examined the effects of ovariectomy on $\mathrm{LH}$ secretion in SL, NL, and LL mice. Because puberty is delayed in LL animals, we performed this experiment in juvenile (P24) mice in an attempt to detect a central defect in gonadotropin secretion near the time of puberty. As previously reported (Prevot et al., 2005), ovariectomy increased LH levels in control

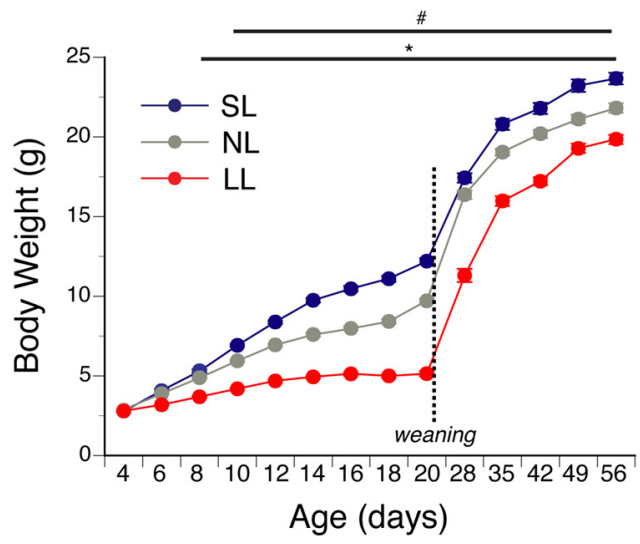

Figure 1. Body weight curves in postnatally overfed and underfed mice. Preweaning and postweaning body weight curves in FVB females raised in SL, NL, and LL ( $n \geq 26$ from at least 4 litters). Animals were allowed access to chow and water ad libitum after weaning. ${ }^{*} p<0.05, \mathrm{SL}$ versus $\mathrm{NL}$; ${ }^{*} p<0.05$, SL and NL versus LL.
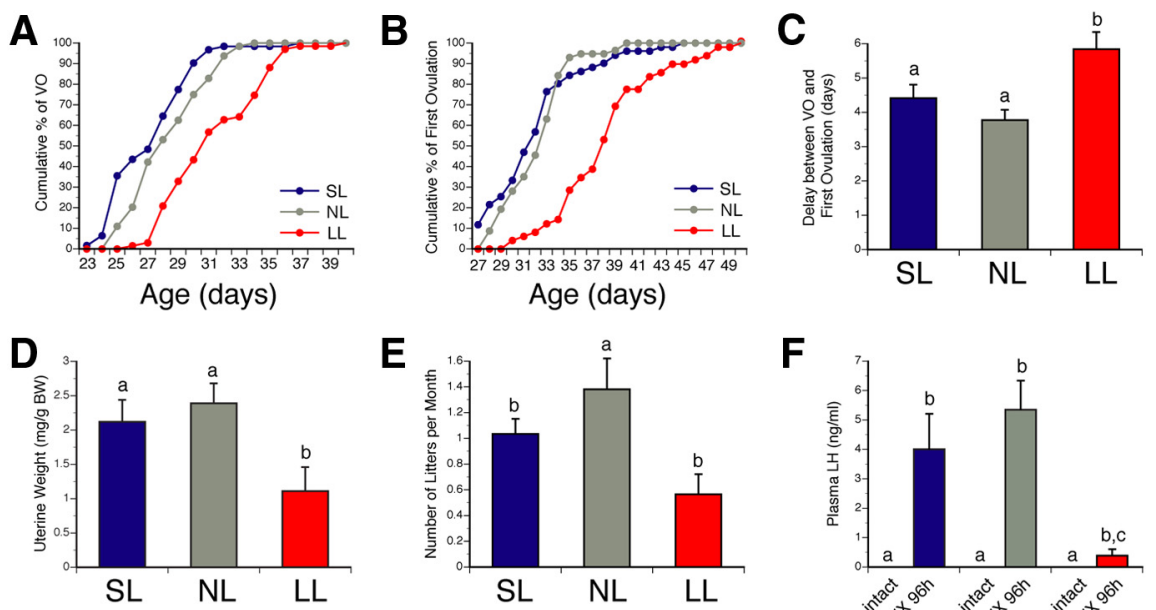

Figure 2. Onset of puberty and adult fertility in postnatally overfed and underfed mice. $\boldsymbol{A}$, Cumulative percentage data for V0 and $L$. $\boldsymbol{E}$, Mean number of litters per month (used as a fertility index) in females raised in SL, NL, and LL. $\boldsymbol{F}$, Mean levels of LH at $96 \mathrm{~h}$ after OVX in P24 female mice raised in SL, NL, and LL. $p<0.05$, a vs b, b vs c; $n \geq 4$ from at least 4 litters.

(NL) juvenile females (Fig. $2 F)(t=6.228, \mathrm{df}=2, p<0.05)$. $\mathrm{LH}$ levels were similar between ovariectomy (OVX) SL and OVX NL mice (Fig. $2 F$ ). In contrast, the LH response to ovariectomy was markedly attenuated in the LL animals (Fig. $2 F)(t=3.869, \mathrm{df}=$ $5, p<0.05)$, indicating that the ability of the GnRH neuronal network to increase its secretory output in response to the loss of ovary-dependent inhibitory control is disrupted in these animals.

\section{Change in neonatal nutrition causes nucleus-specific structural alterations in kisspeptin circuits}

Because kisspeptin neurons have been reported to play a central role in pubertal activation (de Roux et al., 2003; Seminara et al., 2003), and because kisspeptin neural circuits develop gradually during the first 2-5 weeks of postnatal life (Clarkson and Herbison, 2006), we next investigated whether neonatal nutritional manipulations impact development of kisspeptin neural projections by performing immunohistochemical labeling of kisspeptin, paying particular attention to projections to the MEPO, a key 



E

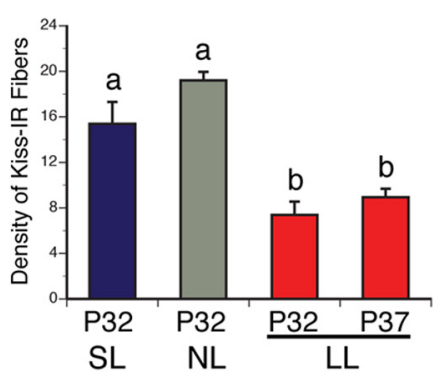

H

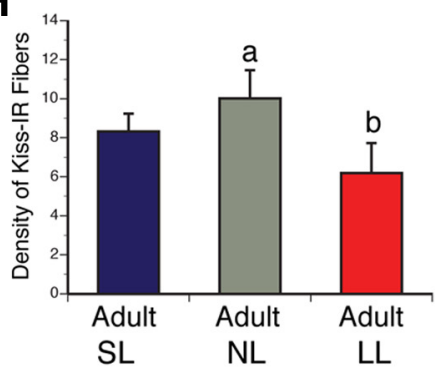

$\mathbf{F}$

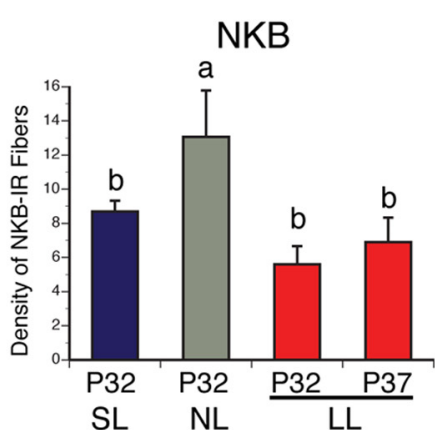

I

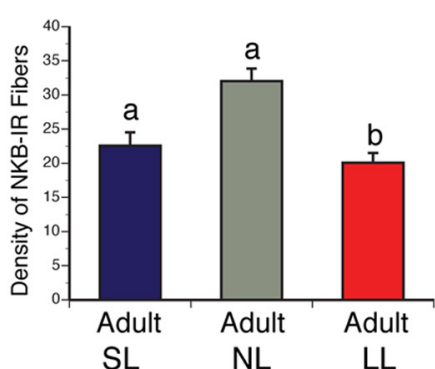

G
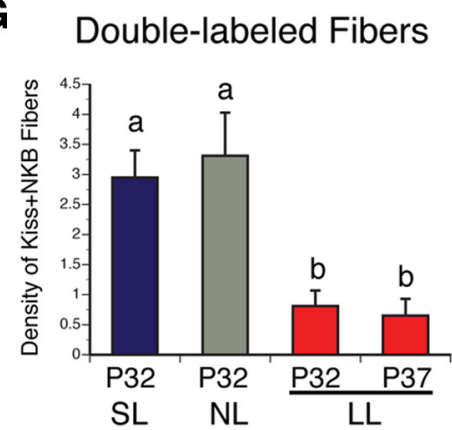

J

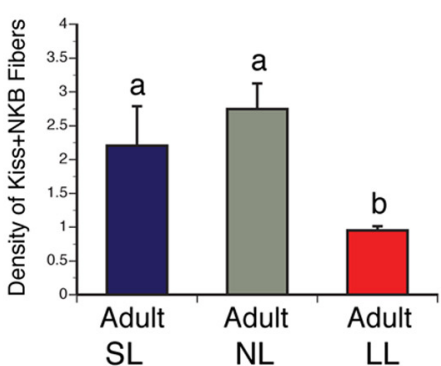

Figure 3. Kisspeptin fibers in postnatally overfed and underfed mice. $\boldsymbol{A}-\boldsymbol{C}$, Confocal images illustrating kisspeptin- $(\boldsymbol{A})$, NKB- $(\boldsymbol{B})$, and kisspeptin + NKB- $(\boldsymbol{C})$ immunoreactivity in the MEPO of P32 diestrous females raised in SL, NL, and LL. $\boldsymbol{D}$, Higher magnification images showing colocalization (yellow) of kisspeptin (green) NKB immunoreactivities in nerve fibers (red). $\boldsymbol{E}-\boldsymbol{J}$, Quantification of kisspeptin- $(\boldsymbol{E}, \boldsymbol{H})$, NKB- $(\boldsymbol{F}, \boldsymbol{I})$, and kisspeptin + NKB- $(\boldsymbol{G}, \boldsymbol{J})$ immunoreactive fibers in the MEP0 of P32 $(\boldsymbol{E}-\boldsymbol{G})$ and adult $(\boldsymbol{H}-\boldsymbol{J})$ diestrous females raised in $S \mathrm{~L}, \mathrm{NL}$, and $L L$ as well as in P37 diestrous females raised in $L L(E-G)$. V3, Third ventricle. $p<0.05$, a vs b; $n=4-6$ from 4 litters. 

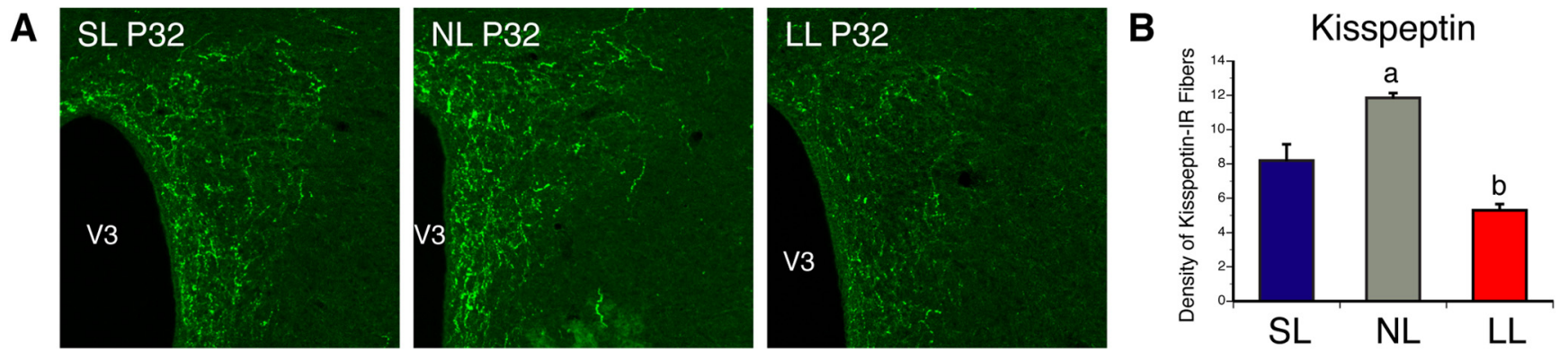

Figure 4. Density of kisspeptin-IR fibers in the PVH of postnatally overfed and underfed mice. $\boldsymbol{A}, \boldsymbol{B}$, Confocal images $(\boldsymbol{A})$ and quantification $(\boldsymbol{B})$ of kisspeptin-immunoreactive fibers in the PVH of P32 diestrous females that were raised in SL, NL, and LL. V3, Third ventricle. $p<0.05$, a vs b; $n=4-6$ from 4 litters.

region involved in reproductive function, and which contains $\mathrm{GnRH}$ neurons. We chose to study kisspeptin projections in females at P32, which is an age when projections of the ARH and AVPV are fully developed (Bouret et al., 2004a; Polston and Simerly, 2006), and when GnRH neurons start to receive projections from kisspeptin neurons and express high levels of the kisspeptin receptor GPR54 (Clarkson and Herbison, 2006; Herbison et al., 2010). We also only studied mice in diestrus to avoid hormonal influences. The density of kisspeptin-IR fibers in the MEPO of undernourished mice at P32 was reduced threefold compared with that observed in control mice (Fig. $3 A, E)(t=$ $6.447, \mathrm{df}=4, p<0.05)$. As observed at P32, the average density of kisspeptin-IR fibers in the MEPO remained diminished in P37 and adult LL mice relative to control mice (Fig. $3 E, H)(t=5.590$, $\mathrm{df}=6, p<0.05)$. Similarly, underfed neonates also displayed a twofold reduction in the density of kisspeptin-IR fibers in the PVH compared with control pups (Fig. 4$)(t=2.753$, $\mathrm{df}=6, p<$ $0.05)$. Conversely, the density of kisspeptin-IR in the MEPO was not different between SL and NL animals (Fig. $3 A, E, H$ ). Also, the distribution pattern of kisspeptin-labeled fibers in the hypothalamus was similar between animals raised in small, normal, and large litters, suggesting that neonatal nutrition alters the density of these fibers but not their pattern of innervation.

Two main populations of kisspeptin neurons exist in the mammalian brain: one located in the ARH and another located more rostrally in the AVPV (Gottsch et al., 2004; Clarkson et al., 2009). To determine which neuronal population is likely to be affected by changes in postnatal nutrition, we next used DiI axonal labeling to study ARH and AVPV neural projections in animals raised in small, normal, and large litters. P16 mice were used in this study, because it is when ARH $\rightarrow$ AVPV projections are established (Bouret et al., 2004a). The density of ARH DiIlabeled fibers in the MEPO of undernourished mice at P16 was 4.6-fold decreased compared with that observed in control mice (Fig. 5A, $C)(t=4.820, \mathrm{df}=3, p<0.05)$. Similarly, overfed neonates also displayed a 1.8 -fold reduction in the density of ARH DiI-labeled fibers in the MEPO compared with control pups (Fig. 5A,C) $(t=4.261$, df $=7, p<0.05)$. However, AVPV $\rightarrow$ MEPO neural projections appeared to be normal in both SL and LL pups (Fig. $5 B, D$ ). Because kisspeptin neurons that express $\mathrm{NKB}$ are restricted to kisspeptin-containing neurons of the ARH (Goodman et al., 2007), NKB-IR fibers can also serve as a marker for projections from ARH kisspeptin neurons (Fig. 3D). As for the axonal labeling study in neonates, the density of ARH NKB-IR fibers found in the MEPO of undernourished females was decreased by twofold compared with that of control mice (Fig. $3 B, F, I)(t=2.586, \mathrm{df}=7, p<0.05)$. Moreover, the density of kisspeptin $+\mathrm{NKB}$ doubly labeled fibers was reduced by threefold in the MEPO of P32 LL mice compared with NL animals (Fig. 3C, G,J) $(t=7.996, \mathrm{df}=6, p<0.05)$. Notably, SL animals also displayed a 1.5 -fold reduction in the density of NKB-IR fibers in the MEPO compared with NL animals (Fig. $3 C, F, I)(t=2.716$, df $=6, p<$ $0.05)$, but the density of kisspeptin $+\mathrm{NKB}$ doubly labeled fibers was comparable between neonatally overfed and control females (Fig. $3 G, J)$. Together with our axonal labeling experiments, these immunohistochemical findings suggest that ARH neural projections are more affected by postnatal undernutrition compared with AVPV projections.

To determine whether neonatal nutrition influences the development of other reproduction-related circuits, we also examined neural projections containing $\mathrm{GnRH}$. Immunohistochemical analysis revealed that this pathway is unaffected by neonatal nutrition, as the density of GnRH-IR fibers in the median eminence, the major projection site for GnRH neurons, was similar in SL, NL, and LL mice (Fig. 6). Together, these observations suggest that alterations in neonatal nutrition do not lead to widespread disruption of hypothalamic circuitries involved in reproduction but specifically affect the development of ARH kisspeptin projections.

\section{Discussion}

It is generally accepted that food availability is the most important factor influencing mammalian reproduction. However, an association between alterations in neonatal nutrition and the development of brain circuits responsible for the regulation of puberty and fertility has never been examined. The neuroanatomical experiments presented here indicate that pups that have been undernourished during early postnatal life display a reduction in the density of kisspeptin-IR fibers compared with normally fed animals. The hypothalamic kisspeptin system has been suggested to play a major role in pubertal activation (de Roux et al., 2003; Seminara et al., 2003). Importantly, the effect of neonatal undernutrition on kisspeptin projections is persistent, and not just a delay. Some of the most severely affected projections were those projecting to the MEPO, a hypothalamic region that contains most of the kisspeptin receptor-expressing $\mathrm{GnRH}$ neurons (Herbison et al., 2010; Hanchate et al., 2012). In particular, the low densities of kisspeptin-IR fibers observed in the MEPO of undernourished females seem to reflect a reduction in the density of kisspeptin projections originating from ARH neurons. Consistent with this idea, our axonal labeling experiments indicate that $\mathrm{ARH} \rightarrow \mathrm{MEPO}$ projections are reduced in undernourished animals, while AVPV $\rightarrow$ MEPO projections are unaltered in neonatally undernourished animals. In addition, both $\mathrm{NKB}-$ and $\mathrm{NKB}+$ kisspeptin-containing projections are reduced in undernourished pups. These results indicate that ARH circuits regulating reproduction are highly plastic and develop in response to food availability, whereas AVPV projections do not appear to be markedly influenced by postnatal nutrition. 

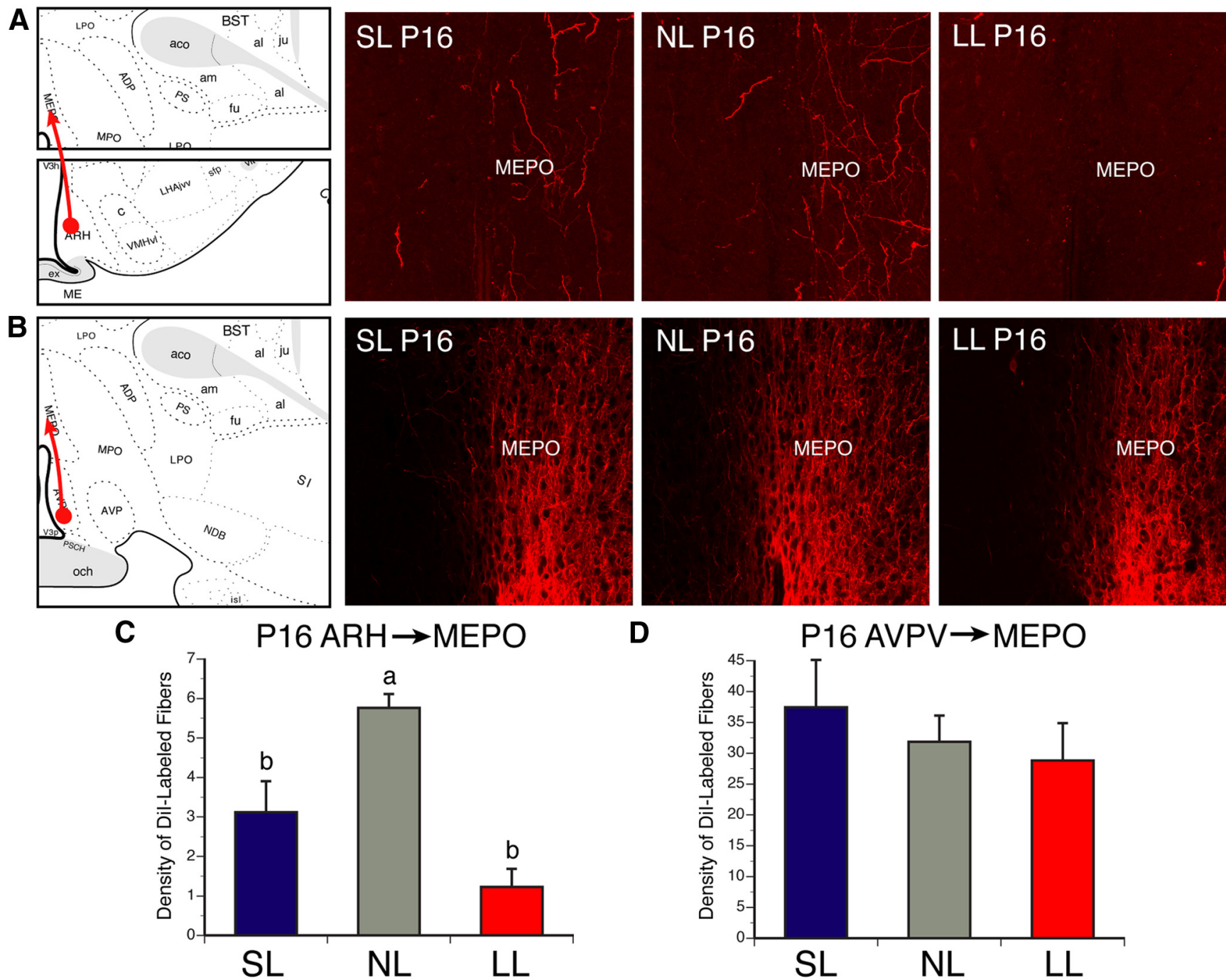

Figure 5. $A-D, A R H \rightarrow M E P O$ and $A V P V \rightarrow M E P O$ axonal projections in postnatally overfed and underfed mice. Confocal images and quantification of $A R H(A, C)$ and $A V P V(B, D)$ fibers labeled with the anterograde tracer Dil and innervating the MEPO of P16 mice raised in SL, NL, and LL. V3, Third ventricle. $p<0.05$, a vs b; $n=4-6$ from 4 litters.
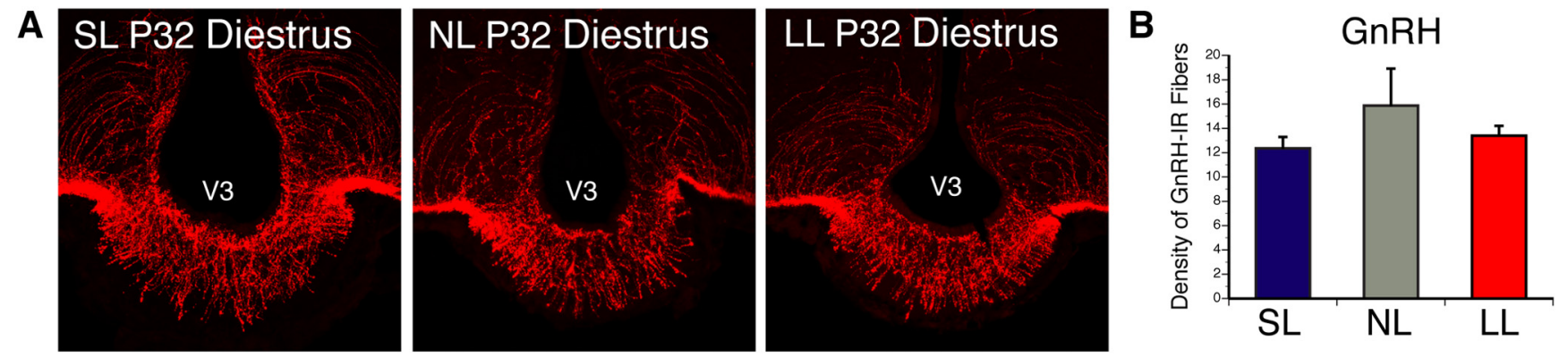

Figure 6. GnRH fibers in postnatally overfed and underfed mice. $A, B$, Confocal images $(\boldsymbol{A})$ and quantification $(\boldsymbol{B})$ of GnRH-immunoreactive fibers in the median eminence of P32 diestrous female mice raised in $\mathrm{SL}, \mathrm{NL}$, and LL. V3, Third ventricle. $p<0.05$, a vs $b ; n=4-6$ from 4 litters.

The fact that AVPV $\rightarrow$ MEPO projections are not affected by postnatal nutrition is not surprising considering that these neural projections develop primarily during intrauterine life and are fully developed before birth (Polston and Simerly, 2006). Moreover, we did not observe any major alterations in the density of GnRH neural projections and these projections also develop during prenatal life (Wu et al., 1997). These results suggest that exposure to environmental nutritional insults is most likely to cause more profound adverse organizational effects when the exposure occurs during development of the nucleus controlling the specific physiological process that is affected. In addition to adversely affecting the organization of neural circuits that ultimately control reproduction, perinatal nutrition also influences other regulatory processes, such as mRNA expression of key neuropeptides involved in reproductive function. For example, a recent study using a similar divergent litter size model showed that rats raised 
in large litters displayed reduced levels of Kiss 1 mRNA in the hypothalamus (Castellano et al., 2011). Notably, in agreement with our findings, this study also found that postnatal underfeeding caused a reduction in uterus weight and a delayed vaginal opening (Castellano et al., 2011). Similar to postnatal undernutrition, intrauterine undernutrition, induced by maternal caloric restriction during pregnancy, results in a reduction in hypothalamic Kiss1 mRNA expression in the female offspring (Iwasa et al., 2010). Remarkably, these changes in gene expression were observed as early as P16 and persisted throughout life. A reduction in Gnrh mRNA expression has also been reported in the hypothalamus of animals born to undernourished dams (Iwasa et al., 2010). These alterations in gene expression were also associated with perturbations in the timing of vaginal opening. Together, these findings suggest that, in addition to postnatal nutrition, nutrition during pregnancy is also an important determinant for postnatal hypothalamic regulation and subsequent function. We cannot exclude in our studies that changes in kisspeptin and/or NKB immunostaining observed in the MEPO of LL mice are not due to alterations in peptide synthesis, transport, or release. However, the observation that DiI-containing projections also appear affected in LL mice support the hypothesis that the low density of kisspeptin-immunoreactive fibers observed in LL mice is due to alterations in axon density as opposed to a reduction in peptide content in axons. Moreover, it remains possible that the development of other non-ARH kisspeptin projections, such as those from the periventricular preoptic nucleus to the MEPO, is also affected by changes in neonatal nutrition.

The physiological and structural alterations induced by neonatal nutrition do not seem to be restricted to neural systems related to reproduction. Rather, the effects of neonatal nutrition appear to be more global and to target a variety of neural pathways sensitive to feeding cues. For example, we recently found that postnatal overfeeding and underfeeding disrupt the normal development of hypothalamic neural circuits involved in appetite regulation (Bouret et al., 2007), with long-term consequences for energy balance regulation (Bouret et al., 2007). Hormonal resistance and increased susceptibility to diet-induced obesity have also been reported in neonatally overfed animals (Glavas et al., 2010). It is well known that the adipocyte-derived hormone leptin reflects the amount of energy stored in adipose tissue (Ahima and Flier, 2000). Notably, we recently found that leptin levels are influenced by postnatal nutrition. Overfed neonates displayed markedly elevated serum levels of leptin, whereas postnatal leptin levels were blunted in the mice from undernourished litters (Bouret et al., 2007). Interestingly, leptin appears to be a major signal for the initiation of puberty and is capable of accelerating the onset of puberty (Ahima et al., 1997). Whether leptin acts directly on arcuate kisspeptin neurons to mediate its regulatory action on the GnRH system remains controversial (Leshan et al., 2009; Donato et al., 2011; Gottsch et al., 2011; Louis et al., 2011). Nevertheless, data indicated that during early postnatal life this hormone also plays a developmental role on neural projections from the arcuate nucleus of the hypothalamus (Bouret et al., 2004b). Because hypothalamic neural circuits involved in reproductive function, including the kisspeptinergic system, develop primarily during the first 3 weeks of postnatal life (Bouret et al., 2004a; Clarkson and Herbison, 2006), it is possible that the reduced leptin levels documented in undernourished pups may underlie the observed perturbations in ARH kisspeptin projections.

Our anatomical analysis indicates that the structural effects of undernutrition are more profound than those of overfeeding. For example, the density of kispeptin-IR fibers in the MEPO were markedly reduced in postnatally undernourished animals but not significantly affected in overnourished females. In addition, neonatally undernourished animals show a delayed puberty onset, whereas neonatally overnourished females do not exhibit obvious pubertal alterations. Notably, in undernourished mice, the retarded puberty is associated with a marked impairment of the peripubertal GnRH/LH system to respond to ovariectomy. These data suggest that the juvenile restraint of $\mathrm{GnRH}$ release, which has recently been shown to require estrogen receptor $\alpha$ signaling in kisspeptin neurons located in the ARH (Mayer et al., 2010), may be ill developed in these animals. This hypothesis is supported with our morphological data showing that $\mathrm{ARH} \rightarrow \mathrm{MEPO}$ projections and the density of $\mathrm{NKB}+$ kisspeptin-containing fibers in the MEPO are markedly reduced in undernourished mice. Altogether, these results are also in good agreement with human studies showing that anorexia or calorie restriction in girls delays puberty. Although overnutrition does not profoundly influence the onset of puberty, it has ultimately deleterious effects on adult reproductive functions. Our animal study shows that neonatally overnourished females have a reduced reproductive performance during adulthood, as shown by a reduction in the number of litters per month. Epidemiological data further support these findings and indicate that obese women are also less fertile (Norman and Clark, 1998). Because NKB plays a fundamental role in normal reproductive function (Rance et al., 2010), the reduction in NKB-IR fibers observed in the MEPO of adult SL mice likely contributes to the defective reproductive performance observed in these animals.

\section{References}

Ahima RS (2004) Body fat, leptin, and hypothalamic amenorrhea. N Engl J Med 351:959-962.

Ahima RS, Flier JS (2000) Leptin. Annu Rev Physiol 62:413-437.

Ahima RS, Dushay J, Flier SN, Prabakaran D, Flier JS (1997) Leptin accelerates the onset of puberty in normal female mice. J Clin Invest 99:391-395.

Biro FM, Khoury P, Morrison JA (2006) Influence of obesity on timing of puberty. Int J Androl 29:272-277.

Bouret SG, Draper SJ, Simerly RB (2004a) Formation of projection pathways from the arcuate nucleus of the hypothalamus to hypothalamic regions implicated in the neural control of feeding behavior in mice. J Neurosci 24:2797-2805.

Bouret SG, Draper SJ, Simerly RB (2004b) Trophic action of leptin on hypothalamic neurons that regulate feeding. Science 304:108-110.

Bouret SG, Burt-Solorzano C, Wang CH, Simerly RB (2007) Impact of neonatal nutrition on development of brain metabolic circuits in mice. Soc Neurosci Abstr 33:300.21/VV8.

Bouret SG, Gorski JN, Patterson CM, Chen S, Levin BE, Simerly RB (2008) Hypothalamic Neural Projections Are Permanently Disrupted in DietInduced Obese Rats. Cell Metabolism 7:179-185.

Bray GA (1997) Obesity and reproduction. Hum Reprod 12:26-32.

Brewer CJ, Balen AH (2010) The adverse effects of obesity on conception and implantation. Reproduction 140:347-364.

Burt Solorzano CM, McCartney CR (2010) Obesity and the pubertal transition in girls and boys. Reproduction 140:399-410.

Castellano JM, Bentsen AH, Sánchez-Garrido MA, Ruiz-Pino F, Romero M, Garcia-Galiano D, Aguilar E, Pinilla L, Diéguez C, Mikkelsen JD, TenaSempere M (2011) Early metabolic programming of puberty onset: impact of changes in postnatal feeding and rearing conditions on the timing of puberty and development of the hypothalamic kisspeptin system. Endocrinology 152:3396-3408.

Ciofi P, Leroy D, Tramu G (2006) Sexual dimorphism in the organization of the rat hypothalamic infundibular area. Neuroscience 141:1731-1745.

Clarkson J, Herbison AE (2006) Postnatal development of kisspeptin neurons in mouse hypothalamus; sexual dimorphism and projections to gonadotropin-releasing hormone neurons. Endocrinology 147:5817-5825. 
Clarkson J, d'Anglemont de Tassigny X, Moreno AS, Colledge WH, Herbison AE (2008) Kisspeptin-GPR54 signaling is essential for preovulatory gonadotropin-releasing hormone neuron activation and the luteinizing hormone surge. J Neurosci 28:8691-8697.

Clarkson J, d'anglemont de Tassigny X, Colledge WH, Caraty A, Herbison AE (2009) Distribution of kisspeptin neurones in the adult female mouse brain. J Neuroendocrinol 21:673-682.

Clarkson J, Han SK, Liu X, Lee K, Herbison AE (2010) Neurobiological mechanisms underlying kisspeptin activation of gonadotropin-releasing hormone $(\mathrm{GnRH})$ neurons at puberty. Molecular and Cellular Endocrinology 324:45-50.

Cravo RM, Margatho LO, Osborne-Lawrence S, Donato J Jr, Atkin S, Bookout AL, Rovinsky S, Frazão R, Lee CE, Gautron L, Zigman JM, Elias CF (2011) Characterization of Kiss1 neurons using transgenic mouse models. Neuroscience 173:37-56.

d'Anglemont de Tassigny X, Fagg LA, Dixon JP, Day K, Leitch HG, Hendrick AG, Zahn D, Franceschini I, Caraty A, Carlton MB, Aparicio SA, Colledge WH (2007) Hypogonadotropic hypogonadism in mice lacking a functional Kiss1 gene. Proc Natl Acad Sci U S A 104:10714-10719.

de Roux N, Genin E, Carel JC, Matsuda F, Chaussain JL, Milgrom E (2003) Hypogonadotropic hypogonadism due to loss of function of the KiSS1derived peptide receptor GPR54. Proc Natl Acad Sci USA 100:10972-10976.

Donato J Jr, Cravo RM, Frazão R, Gautron L, Scott MM, Lachey J, Castro IA, Margatho LO, Lee S, Lee C, Richardson JA, Friedman J, Chua S Jr, Coppari R, Zigman JM, Elmquist JK, Elias CF (2011) Leptin's effect on puberty in mice is relayed by the ventral premammillary nucleus and does not require signaling in Kiss 1 neurons. J Clin Invest 121:355-368.

Ebbeling CB, Pawlak DB, Ludwig DS (2002) Childhood obesity: publichealth crisis, common sense cure. Lancet 360:473-482.

Elmquist JK, Coppari R, Balthasar N, Ichinose M, Lowell BB (2005) Identifying hypothalamic pathways controlling food intake, body weight, and glucose homeostasis. J Comp Neurol 493:63-71.

Euling SY, Selevan SG, Pescovitz OH, Skakkebaek NE (2008) Role of environmental factors in the timing of puberty. Pediatrics 121:S167-S171.

Fernandez-Fernandez R, Martini AC, Navarro VM, Castellano JM, Dieguez C, Aguilar E, Pinilla L, Tena-Sempere M (2006) Novel signals for the integration of energy balance and reproduction. Mol Cell Endocrinol 254-255:127-132.

Foster DL, Olster DH (1985) Effect of restricted nutrition on puberty in the lamb: patterns of tonic luteinizing hormone (LH) secretion and competency of the LH surge system. Endocrinology 116:375-381.

Franklin BJ, Paxinos G (2008) The mouse brain in stereotaxic coordinates. San Diego: Academic.

Glavas MM, Kirigiti MA, Xiao XQ, Enriori PJ, Fisher SK, Evans AE, Grayson BE, Cowley MA, Smith MS, Grove KL (2010) Early overnutrition results in early-onset arcuate leptin resistance and increased sensitivity to highfat diet. Endocrinology 151:1598-1610.

Godfrey KM, Gluckman PD, Hanson MA (2010) Developmental origins of metabolic disease: life course and intergenerational perspectives. Trends Endocrinol Metab 21:199-205.

Goodman RL, Lehman MN, Smith JT, Coolen LM, de Oliveira CV, Jafarzadehshirazi MR, Pereira A, Iqbal J, Caraty A, Ciofi P, Clarke IJ (2007) Kisspeptin Neurons in the Arcuate Nucleus of the Ewe Express Both Dynorphin A and Neurokinin B. Endocrinology 148:57525760 .

Gottsch ML, Cunningham MJ, Smith JT, Popa SM, Acohido BV, Crowley WF, Seminara S, Clifton DK, Steiner RA (2004) A role for kisspeptins in the regulation of gonadotropin secretion in the mouse. Endocrinology 145:4073-4077.

Gottsch ML, Popa SM, Lawhorn JK, Qiu J, Tonsfeldt KJ, Bosch MA, Kelly MJ, Rønnekleiv OK, Sanz E, McKnight GS, Clifton DK, Palmiter RD, Steiner RA (2011) Molecular Properties of Kiss1 Neurons in the Arcuate Nucleus of the Mouse. Endocrinology 152:4298-4309.

Grumbach MM, Styne DM (1998) Puberty: ontogeny, neuroendocrinology, physiology, and disorders. In: Williams textbook of endocrinology (Williams RH FD, Kroenenberg H, Larsen PR, Zorab R, eds), pp 15091625. Philadelphia: Saunders.
Hanchate NK, Parkash J, Bellefontaine N, Mazur D, Colledge WH, d'Anglemont de Tassigny X, Prevot V (2012) Kisspeptin-GPR54 signaling in mouse NO-synthesizing neurons participates in the hypothalamic control of ovulation. J Neurosci 32:932-945.

Herbison AE (2006) Physiology of the gonadotropin-releasing hormone neuronal network. In: Knobil and Neil's physiology of reproduction (Neill JD, ed), pp 1415-1482: Elsevier.

Herbison AE, Porteous R, Pape JR, Mora JM, Hurst PR (2008) Gonadotropin-Releasing Hormone Neuron Requirements for Puberty, Ovulation, and Fertility. Endocrinology 149:597-604.

Herbison AE, d'Anglemont de Tassigny X, Doran J, Colledge WH (2010) Distribution and postnatal development of Gpr54 gene expression in mouse brain and gonadotropin-releasing hormone neurons. Endocrinology 151:312-321.

Herman-Giddens ME, Slora EJ, Wasserman RC, Bourdony CJ, Bhapkar MV, Koch GG, Hasemeier CM (1997) Secondary sexual characteristics and menses in young girls seen in office practice: a study from the pediatric research in office settings network. Pediatrics 99:505-512.

Hileman SM, Pierroz DD, Flier JS (2000) Leptin, nutrition, and reproduction: timing is everything. J Clin Endocrinol Metab 85:804-807.

Hill JW, Elmquist JK, Elias CF (2008) Hypothalamic pathways linking energy balance and reproduction. Am J Physiol Endocrinol Metab 294:E827-E832.

Iwasa T, Matsuzaki T, Murakami M, Fujisawa S, Kinouchi R, Gereltsetseg G, Kuwahara A, Yasui T, Irahara M (2010) Effects of intrauterine undernutrition on hypothalamic Kiss1 expression and the timing of puberty in female rats. J Physiol 588:821-829.

Kaplowitz P (2006) Pubertal development in girls: secular trends. Curr Opin Obstet Gynecol 18:487-491.

Kennedy GC, Mitra J (1963) Body weight and food intake as initiating factors for puberty in the rat. J Physiol 166:408-418.

Lehman MN, Merkley CM, Coolen LM, Goodman RL (2010) Anatomy of the kisspeptin neural network in mammals. Brain Res 1364: 90-102.

Leshan RL, Louis GW, Jo YH, Rhodes CJ, Münzberg H, Myers MG Jr (2009) Direct innervation of GnRH neurons by metabolic- and sexual odorantsensing leptin receptor neurons in the hypothalamic ventral premammillary nucleus. J Neurosci 29:3138-3147.

Levin BE (2006) Metabolic imprinting: critical impact of the perinatal environment on the regulation of energy homeostasis. Philos Trans R Soc Lond B Biol Sci 361:1107-1121.

Louis GW, Greenwald-Yarnell M, Phillips R, Coolen LM, Lehman MN, Myers MG Jr (2011) Molecular mapping of the neural pathways linking leptin to the neuroendocrine reproductive axis. Endocrinology 152:2302-2310.

Martin-Gronert MS, Ozanne SE (2005) Programming of appetite and type 2 diabetes. Early Hum Dev 81:981-988.

Mason AJ, Hayflick JS, Zoeller RT, Young WS 3rd, Phillips HS, Nikolics K, Seeburg PH (1986) A deletion truncating the gonadotropin-releasing hormone gene is responsible for hypogonadism in the hpg mouse. Science 234:1366-1371

Mayer C, Boehm U (2011) Female reproductive maturation in the absence of kisspeptin/GPR54 signaling. Nat Neurosci 14:704-710.

Mayer C, Acosta-Martinez M, Dubois SL, Wolfe A, Radovick S, Boehm U, Levine JE (2010) Timing and completion of puberty in female mice depend on estrogen receptor alpha-signaling in kisspeptin neurons. Proc Natl Acad Sci U S A 107:22693-22698.

Nelson JF, Karelus K, Felicio LS, Johnson TE (1990) Genetic influences on the timing of puberty in mice. Biol Repr 42:649-655.

Norman RJ, Clark AM (1998) Obesity and reproductive disorders: a review. Reprod Fertil Dev 10:55-63.

Ojeda SR, Skinner MK (2006) Puberty in the rat. In: Knobil and Neill's physiology of reproduction (Neill JD, ed), pp 2026-2126. San Diego: Academic.

Ong KK, Ahmed ML, Dunger DB (2006) Lessons from large population studies on timing and tempo of puberty (secular trends and relation to body size): the European trend. Mol Cell Endocrinol 254:8-12.

Plagemann A (2006) Perinatal nutrition and hormone-dependent programming of food intake. Horm Res 65 [Suppl 3]:83-89.

Polston EK, Simerly RB (2006) Ontogeny of the projections from the an- 
teroventral periventricular nucleus of the hypothalamus in the female rat. J Comp Neurol 495:122-132.

Prevot V, Lomniczi A, Corfas G, Ojeda SR (2005) erbB-1 and erbB-4 receptors act in concert to facilitate female sexual development and mature reproductive function. Endocrinology 146:1465-1472.

Rance NE, Krajewski SJ, Smith MA, Cholanian M, Dacks PA (2010) Neurokinin B and the hypothalamic regulation of reproduction. Brain Res 1364:116-128.

Seminara SB, Messager S, Chatzidaki EE, Thresher RR, Acierno JS Jr, Shagoury JK, Bo-Abbas Y, Kuohung W, Schwinof KM, Hendrick AG, Zahn D, Dixon J, Kaiser UB, Slaugenhaupt SA, Gusella JF, O’Rahilly S, Carlton MB, Crowley WF Jr, Aparicio SA, Colledge WH (2003) The GPR54 gene as a regulator of puberty. $\mathrm{N}$ Engl J Med 349:1614-1627.

Sullivan EL, Grove KL (2010) Metabolic imprinting in obesity. Forum Nutr 63:186-194
Swanson LW (1992) Brain maps: structure of the rat brain. Amsterdam: Elsevier Science.

Wade GN, Schneider JE, Li HY (1996) Control of fertility by metabolic cues. Am J Physiol Endocrinol Metab 270:E1-E19.

Walvoord EC (2010) The timing of puberty: is it changing? Does it matter? J Adolesc Health 47:433-439.

Wu TJ, Gibson MJ, Rogers MC, Silverman AJ (1997) New observations on the development of the gonadotropin-releasing hormone system in the mouse. J Neurobiol 33:983-998.

Wyshak G, Frisch RE (1982) Evidence for a secular trend in age of menarche. N Engl J Med 306:1033-1035.

Yeo SH, Herbison AE (2011) Projections of arcuate nucleus and rostral periventricular kisspeptin neurons in the adult female mouse brain. Endocrinology 152:2387-2399. 